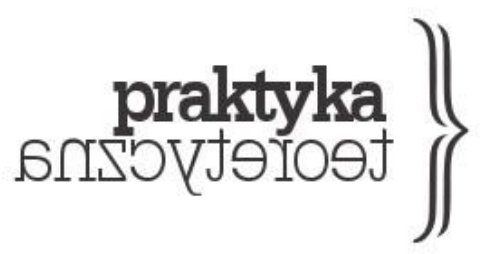

Praktyka Teoretyczna

Numer 1(19)/2016

ISSN 2081-8130

DOI: $10.14746 /$ prt.2016.1.14

www.praktykateoretyczna.pl

\title{
WIDMOWA AKTUALIZACJA MARKSIZMU, CZY SPEKTRALNA BUJDA
}

JĘDRZEJ BRZEZIŃSKI

\begin{abstract}
Abstrakt: Artykuł jest krytyczna interpretacją Widm Marksa Jacquesa Derridy. Obok przedstawienia krytycznych odczytań Eagletona czy Negriego, próbuję pokazać nie tylko filozoficzna jałowość propozycji Derridy, ale także niezdolność do wywiązania się z politycznych i etycznych obietnic, które składa.
\end{abstract}

Słowa kluczowe: Derrida, marksizm, widmontologia, ofelizm, dekonstrukcja 
Rzeczywiście trudno jest nie zacząć od pytania o aktualność (lub niewczesność) Widm Marksa Jacques’a Derridy, a także ich wydanego właśnie polskiego przekładu (którego autorowi, Tomaszowi Załuskiemu, należą się wyrazy uznania), jeszcze trudniej jednak na pytanie to odpowiedzieć. Derrida, za Hamletem, daje pewną podpowiedź - i ona jednak bardzo niewiele rozjaśnia. Jeśli bowiem czas jest „jak kość wyłamana w stawie”, jeśli czas „wyszedł z formy”, to wcale nie po to, by dać się jakkolwiek wyregulować. Nastawić - przeczuwa już Hamlet można kość albo zegar, ale nigdy sam czas. Niepunktualność nie jest nigdy punktowa. Pomysłowa przesłanką tekstu Derridy jest ekstrapolacja tej w istocie ontologicznej asercji na sferę polityki - także i ona jest dla niego dziedziną działań niesynchronicznych, zawsze punktowych, nigdy punktualnych, ujawniających w czasie swą nietożsamość z soba. Ambicją Derridy nie jest jednak wcale jakkolwiek zaradzić tej asynchronii - nie ma on tej wiary, której resztkę żywił jeszcze jego tragiczny prekursor, Hamlet, do końca licząc - wbrew wszystkiemu - że zdąży wypełnić to, co postanowił. Nie wierzy też Derrida, że „sowa Minerwy wylatuje o zmierzchu" - konstatacja ta wciąz zakłada bowiem postęp, przekonanie, że jednak, at the end of the day, stajemy mądrzejsi, także względem czasu (Derrida mógłby raczej powtórzyć za Poloniuszem: „chcieć określić (...) / Dlaczego dzień jest dniem, a noc jest noca,/ A czas jest czasem, byłoby to jedno,/ Co chcieć zmarnować dzień, noc i czas drogi’”). Dlatego kolejną ze stawek Widm Marksa okazuje się eliminacja dialektyki, czyli procedury, która w ciągłym „nadganianiu” świata przy pomocy pojęć widziała istotę myślenia. I stąd same widma: fantomy, spektra, duchy, których półistnienie ma zastapić pozytywność Heglowskiego Ducha z jego pretensją do pełnej obecności. Dlatego właśnie czytać będzie Derrida „Marksa Hamletem" - odcinając go tym samym od filozoficznej tradycji, z której się wywodzi, a także od towarzyszy, bez których niemożliwe byłoby jego dzieło. To pierwsze z naszych podejrzeń wobec zasadności Derridiańskiej lektury: hamletyzując Marksa, zatraca autor jego najżywotniejsze atuty. W ten sposób niewatpliwe zdobycze jego materialistycznych analiz zasnuwa widmową mgła, a efekty wytężonych poszukiwań ognisk rzeczywistej społecznej zmiany rozmywa w fałszywym obrazie myśli skrajnie niezdecydowanej. Marks, w wersji Derridy, wywołuje duchy, z którymi nie wie, co zrobić; zrazu chwali „potęgę sił rozpętanych przez kapitalizm”, tylko po to jednak, by zaraz rzucać na nie kontrzaklęcia i egzorcyzmy. Wydaje się nam jednak, że autor Kapitału jest dużo bardziej konsekwentny niż Hamlet - i to dopiero Derrida wysłuży się jego „widmami”, by móc wpisać go w swą retorykę różni. Czołowa zasada tej ostatniej, będąca naszym zdaniem także głównym powodem porażki „derridiańskiego marksizmu”, to utożsamienie warunku możliwości z warunkiem niemożliwości. Jakkolwiek efektownie brzmi stwierdzenie, że warunkiem możliwości sprawiedliwości jest jej nieusuwalna niemożliwość - a to kluczowa teza książki Derridy wydaje się nam, że po chwili krytycznego namysłu wychodzi z niej banał (bo gdyby wszystko było absolutnie sprawiedliwe, nie mówilibyśmy w ogóle o sprawiedliwości, ani nie chcieli 
działać w jej imieniu) - albo aporia, której „,wewnętrzne napięcie” (ulubiony koncept naszych post-heglistów) być może i daje się przełożyć na napęd dla kolejnych i kolejnych tekstów, ale dla sprawiedliwości, która ostatecznie jest przecież rozstrzyganiem, wynika z niej niewiele. Być może tylko zastrzeżenie, że rozstrzyganie jest trudne i złożone, bo zawsze wykraczać musi poza pozytywność swych przesłanek i brać pod uwagę także to, co niewiadome - ale o tym już chyba wiedzieliśmy.

„Dekonstrukcja, przynajmniej w moich oczach, miała sens i była interesująca jedynie jako radykalizacja określonego typu marksizmu" (Derrida 2016, 154) - stwierdza Derrida, i choć próbuje wytłumaczyć na czym owo „radykalizowanie” miałoby polegać - bowiem „nie jest to słowo, które sprawdzałoby się na dłuższa metę" (Derrida 2016, 155) - to jednak trudno zrozumieć, co tak naprawdę chce powiedzieć. Próżno szukać w jego wcześniejszych tekstach jakichkolwiek znaczących nawiązań do filozofa z Trewiru, podobnie zreszta jak „pytań, formalizacji i procedur genealogicznych” mających na celu dekonstrukcjonistyczne kwestionowanie marksizmu (Derrida 2016, 155). Domyślamy się, że owym radix będzie dla Derridy właśnie sprawiedliwość - gdzie indziej filozof stwierdzi po prostu, że „dekonstrukcja jest sprawiedliwością" (cyt. za Sadzik 2016; podkr. JB); darujmy sobie jednak dociekanie, czy - zgodnie z logiką różni - znaczy to także, że jest nią tylko o tyle, o ile jest również niesprawiedliwością. Zanim spytamy o właściwy sens tych utożsamień, spróbujmy najpierw odpędzić (może uda się to choćby na chwilę) wszechobecne widma, także te tytułowe, i zobaczyć, co w kwestii sprawiedliwości do powiedzenia ma sam Marks. Czytelniczka, która do jego tekstów zajrzałaby głębiej dopiero po lekturze Widm, z pewnym zaskoczeniem odkryłaby, że nie odwołuje się on do tego pojęcia prawie wcale, a jeśli już, to czyni to w sposób wyjątkowo podejrzliwy i krytyczny. W Krytyce Programu Gotajskiego zapytuje ostro:

Cóż to jest „sprawiedliwy” podział? Czyż burżua nie zapewnia, że dzisiejszy podział jest „sprawiedliwy"? I czyż istotnie nie jest on jedynym „sprawiedliwym” podziałem na gruncie dzisiejszego sposobu produkcji? Czy stosunki ekonomiczne są regulowane przez pojęcia prawne, czy też, na odwrót, stosunki prawne wynikają z ekonomicznych? (Marks 1947, 404-405)

Ideę „sprawiedliwego podziału” i „równego prawa” nazywa Marks wprost „składanka wyświechtanych frazesów” i ,ideologiczną blaga” (Marks 1947, 405). Oczywiście nie świadczy to wcale o jego moralnej indyferencji i ślepocie na przejawy niesprawiedliwości. Marks dostrzega po prostu, że „sprawiedliwość” nie jest pojęciem nadrzędnym wobec społecznych realiów (jak chciałby tego idealizm lub mesjanizm), ale ściśle podporządkowanym retoryce $\mathrm{i}$ interesom klasy dominującej. I to dlatego unika odwoływania się do niej i niestrudzenie podejmuje wysiłek formułowania takich pojęć, które sprawę z rzeczywistej niesprawiedliwości (wyzysku, alienacji, kradzieży efektów pracy robotników) zdawałyby 
inaczej, niż za pomoca postulatywnego słownika moralności. Podsumowując: Marks świadom jest, że o tym, co jest „sprawiedliwe”, decyduje klasa rządząca, z tego także względu sprawiedliwości nie można wywalczyć inaczej niż przez krytykę prawnych i ekonomicznych urządzeń, które klasa ta sankcjonuje. Derrida także zauważa tę niewspółmierność „rzeczywistej” i „oficjalnej” wersji sprawiedliwości, reaguje na nia jednak w sposób, który każe podejrzewać, że powyższe rozważania nie bardzo go przekonuja. I on zauważa co prawda, że sprawiedliwość (ta rzeczywista) pozostaje nieraz w sprzeczności z tym, co sankcjonuje obowiązujący dyskurs. Jego odpowiedzią jest jednak uznanie - arbitralne i dość pośpieszne - rozłączności domeny sprawiedliwości i domeny prawa. Sprawiedliwość, za którą się opowiada, nie jest symetryczna, dystrybutywna, wyrównująca i zagwarantowana nieuchronnością kary. Nie unifikuje, ale indywidualizuje - jest, ściśle rzecz biorąc, antynomiczna. Wynikają stąd dwa poważne problemy, które naszym zdaniem kompromitują propozycję Derridy. Po pierwsze: dlaczego to właśnie sprawiedliwość miałaby być indywidualizująca? Czyż zasadnicza intuicja, którą nasuwa wszystkim pojęcie sprawiedliwości, nie opiera się właśnie na pewnej podstawowej równości wobec jakiejś wartości lub normy, przekraczającej to, co indywidualne? Możemy spierać się, czy owa norma lub wartość jest słuszna czy nie, ale już sama możliwość tych sporów zakłada, że uznajemy istnienie czegoś, co przewyższa jed nostkowe roszczenia. Po drugie - jeśli sprawiedliwość jest przeciwieństwem prawa, to dokonywać się musi poza nim. Prawo w takim wypadku byłoby domeną czystej niesprawiedliwości - a to, mimo wszystko, absurd.

Jeśli jednak trzymać się założeń samej dekonstrukcji, argument ten nie ma mocy sprawiedliwość nie jest po prostu antytezą niesprawiedliwości, nie rozdziela ich wyłączająca alternatywa, ale raczej splata paradoksalna logika różni. Nie będąc jednak w stanie prowadzić dyskusji na tym gruncie, spróbujmy raczej przeczytać Derridę genetycznie, tropiąc ślady jego inspiracji. Z pewnym zaskoczeniem zauważyć można, że autor, w rozdziale, w którym formułuje jedną z głównych tez książki - tę o związku dekonstrukcji i sprawiedliwości - do Karola Marksa nie odwołuje się wcale. Okazuje się, że za jego dywagacjami stoi tak naprawdę inna inspiracja - myślimy oczywiście o Martinie Heideggerze. Nie trzeba tu zresztą wiele dociekliwości: autor do rozważań ontologa z Meßkirch nawiązuje obszernie i z ufnością równą chyba tylko beztrosce, z jaką przemilcza w tej kwestii opinie samego Marksa. Predylekcja do autora Bycia i çasu tłumaczyć może także, dlaczego to Hamlet uznany został za postać kluczowa dla proponowanego odczytania, mimo że trudno dopatrzeć się w nim choćby jednej cechy marksisty. Czyż nie jest on raczej, w swej tragicznej bieganinie, zneurotyzowany przez upływajacy czas, idealną prefiguracją Heideggerowskiego Sein zum Tode? Czy kiedy „zapytuje”:

Mnież to przystoi, synowi, 


\begin{abstract}
Jedynakowi zamordowanego
Drogiego ojca, od nieba i piekła

Powołanemu do zemsty, jak baba

Marnymi słowy dawać folgę sercu

I na przekleństwach czas trawić jak prosta,

Karczemna dziewka?! (Szekspir 1958, 69)
\end{abstract}

nie ujawnia tym samym, że to śmierć (w tym przypadku ojca) jest wydarzeniem w całości determinującym jego „egzystencjalny horyzont”? Zdaniem Derridy jednak zadawanie śmierci także może być darem, bowiem nie bardzo liczy się co daru, ale tylko jego jak - jego pozostawanie w aporetycznej szczelinie poza obecnością, jego oscylacja między dwoma widmobecnościami. I to właśnie ten aporetyczny dar, którego, jak wynikałoby ze słów Derridy, nikt nigdy nie dał, ani nie otrzymał, stanowi wzorzec działań sprawiedliwych. Oto clou Derridiańskiego pomysłu:

\begin{abstract}
Nie chodzi jednak o sprawiedliwość mierzalną i dystrybutywną. Nie chodzi o prawo (le droit), rachunek restytucji, ekonomię zemsty lub kary (...). Nie chodzi więc o równość mierzalną, o możliwość symetrycznego i synchronicznego obrachunku bądź rozliczenia podmiotów lub przedmiotów ani też o oddanie sprawiedliwości (rendre justice), jeśli ogranicza się ono do potwierdzenia, przywrócenia, egzekwowania prawa (faire droit), lecz o sprawiedliwość jako nieobliczalność daru i jednostkowość anekonomicznej eks-pozycji na innych (Derrida 2016, 49).
\end{abstract}

Poza pretensjonalnością Heideggerowskiego żargonu, który swą pastoralną dykcją nieuchronnie naznacza wywód samego Derridy, odbija się na nim także inne z zasadniczych „rozstrzygnięć” niemieckiego myśliciela: apodyktyczne rozdzielenie i przeciwstawienie Bycia i tego, co istniejace. Nie zrozumie widmologii ten, kto nie zda sobie sprawy, jak długi jest cień rzucany przez ideologię Bycia na filozofię Derridy, z jej ekstrawaganckimi amalgatami (obecność bez obecności, mesjanizm bez mesjanizmu etc.). Tylko w tym kontekście zrozumiałe staje się także, dlaczego owa nieobliczalna, „słabo-mesjaniczna” sprawiedliwość miałaby przeciwstawiać się i przewyższać sprawiedliwość opartą na równości: ponieważ nie bazuje na relacjach między istniejącymi, ale na odniesieniu do tego, co między obecnościa a nieobecnością, jak widmo lub Bycie. Dlatego też ,inni” to nigdy konkretni, obecni inni, ale właśnie inni widmowi. Niezrozumiałe pozostaje jednak jakie środki (poza darem, i tak niemożliwym) miałaby sprawiedliwość ta zatrudniać, by wypełnić swe szumne obietnice. Rozstrzygające, choć ukryte, okazuje się właśnie czyste przeciwstawienie między Byciem 
a bytami, albo raczej - w wersji Derridy - „przeciwstawienie bez przeciwstawienia”, które skądinąd trafnie punktuje Terry Eagleton:

Oto szczyt poststrukturalistycznych fantazji: przeciwstawienie poza przeciwstawieniem, poza wszystkim, co tak niesmacznie systemowe i ponuro „ortodoksyjne” jak przeciwstawienie, spór, ale poza w szelkim dającym się sformułow ać dyskursem, obietnica, którą zdradzi jej własne spełnienie, permanentna, podekscytowana otwartość na Mesjasza, który wyrządziłby nam jednak największą krzywdę, dopuszczając się czegoś tak określonego, jak przyjście (Eagleton 2008, 87).

W efekcie można więc zarzucić Derridzie to, co Heideggerowi zarzuca Theodor Adorno fakt, że chcąc nie chcąc, popada on w idealizm, od którego usilnie stara się zdystansować. W ten sposób, tak jak Heglowski Duch absolutny i Heideggerowskie Bycie, także owa „nieobliczalna sprawiedliwość” okazuje się być czymś dowolnie ustanowionym.

Wydaje nam się, że trudno sprowadzić powyższe problemy do interpretacyjnej złej woli (czy intelektualnego prostactwa), jak choćby w kontekście komentarza Eagletona czyni to Agata Bielik-Robson. Filozofka, chcąc widzieć w subtelności Derridy heroizm nieuproszczonej refleksji, tak niezbędnej (choć brakującej) w „demokratyczno-liberalnym mainstreamie", podkreśla, że autor ten nie tylko formułuje aporie, ale także stara się je przekroczyć, znaleźć drogi wyjścia z nich. Szkoda jednak, że w kwestii owych dróg autorka pozostaje dużo bardziej oszczędna i ezopowa niż w swych pouczeniach pod adresem „młodych, niecierpliwych marksistów”. Ciekawsza wydaje się nam wcześniejsza, bardziej podejrzliwa interpretacja zaproponowana przez Bielik-Robson w jej książce „Na pustyni”. Kryptoteologie późnej nowoczesności, gdzie autorka widzi w Derridzie właśnie przede wszystkim spadkobiercę Heideggera i jego ,żargonu Gelassenheit’. Jego kontynuacją byłaby Derridiańska „retoryka aporetyczna”, która, jak pisze ABR:

\footnotetext{
zbyt szybko piętrzy przed myślą aprioryczne blokady. Wydaje się nam bowiem, że w derridiańskiej aporii odsłania się nie tyle żelazna logika niemożliwości, co, dokładnie przeciwnie, pewien decyzjonistyczny naddatek roæstrsyggajacy na korzyść tego, co niemożliwe i paraliżujące, kosztem tego, co wykonalne i co chciałoby posuwać się dalej (Bielik-Robson 2008, 104).
}

Autorka nie precyzuje, na czym polegać mogłaby różnica między ową aporią blokująca, której doszukała się we wczesnych pismach Derridy, a tą, która w Widmach Marksa miałaby okazać się źródłem twórczego potencjału czy wręcz ruchu naprzód. Podejrzewamy jednak, że w międzyczasie stała się ona czymś innym: jednocześnie pokomplikowaną i rozrzedzona, osobliwą i miękką wersją heglowskiej (czy raczej postheglowskiej) sprzeczności, a przecież nie 
o to Derridzie chodziło. Chodziło mu o to, by utrzymać aporię w jej radykalnie jednostkowym charakterze, umykającym wszelkim związkom z ogólnością. Naszym zdaniem jednak przytaczana w „Na pustyni” krytyka Rodophe’a Gaschégo pozostaje w mocy:

Pojedynczość pojęta w tak skrajny sposób, czyli odmawiająca wszelkiego przekładu $\mathrm{i}$ interpretacji, staje się nieprzejrzysta, niema i bezpośrednia w sensie niedialektycznym. Staje się po prostu najzwyczajniej niezrozumiała. Tego rodzaju słowo pojedyncze byłoby całkowitą klęską jako słowo. Bez wydania się na ryzyko odniesienia do ogólności nie mogłoby nawet zostać rozpoznane jako pojedyncze (cyt. za BielikRobson 2008, 126).

Spostrzeżenie, jakoby u „późnego Derridy” dokonywał się „polityczny zwrot”, okazuje się więc powierzchowne - mamy tu raczej do czynienia z kontynuacją rozpoczętego już w Glosie i fenomenie przedsięwzięcia podminowywania ontologii obecności (obejmującej takie kategorie jak podmiot, znaczenie, pragnienie czy sens) przez teorię aporetycznej jednostkowości, która - jak zaraz pokażemy - wcale nie radzi sobie z zadaniem faktycznej ochrony jednostkowego życia. Dlatego też krytyka Gaschégo daje się odnieść także do późnego dyskursu Derridy, w którym co prawda nie chodzi już o semiotyczne problemy kategorialności i oznaczania, ale sprawę, wydawałoby się, tak konkretna jak etyczność. Derrid a powiela w tym kontekście idee Emanuela Levinasa (do czego zresztą niemal się nie przyznaje) ${ }^{1}$. To od Levinasa pochodzi bowiem koncepcja etyczności jako całkowitego otwarcia na inność, na Innego, który nie daje się wpisać w żadną z ogólnych kategorii, jakimi dysponuje poznanie; koncepcja, którą Derrida powtarza w niemal niezmienionej składni. W efekcie do etyczności derridiańskiej odnieść można również zarzut formułowany często pod adresem Levinasa, taki mianowicie, że jego etyka, mimo niezwykle radykalnych wymagań, jakie deklaruje, sprowadza się ostatecznie do niczego nie problematyzującej i nieoperatywnej bierności, która jedynie wsłuchuje się w apel twarzy Innego, nawołujący by powstrzymać się od wyrządzania krzywdy. Bo czy ostatecznie jedyna praxis, jaką odważy się wskazać Derrida, nie jest owa „praca żałoby”, dla której właściwym etycznym impulsem są tylko głosy zza grobu? I która - ostatecznie niewiele ma chyba wspólnego z praca, skoro nie stawia sobie za zadanie zmiany rzeczywistości, a najwyżej zmianę samego pogrążonego w żałobie podmiotu, przekroczenia jego traumy (śmierci), traumy sprowadzającej duchy, z którymi należy „coś zrobić”, czyli - jak mówi Jakub Momro:

\footnotetext{
${ }^{1}$ Spostrzeżenie to zawdzięczamy Mardie Olesik, która derridiańską etyczność porównała do pozbawionego nie tylko ogólności, ale też konkretnośd „ruchu dwóch wirtualnośd, które mogą jedynie przelatywać przez siebie, w warunkach wszechobecnej widmowośc nie znajdą bowiem nic, czego jakkolwiek można by się złapać”.
} 
niekoniecznie o nich zapomnieć, ale też zbytnio ich nie celebrować czy fetyszyzować, (...) obłaskawić demony pamięci czy historii, nieco je zneutralizować, ale jednocześnie się nimi bawić, prowadzić z nimi estetyczną czy intelektualną grę, której pełno jest w popkulturze (Momro 2016).

Wydaje się nam jednak, że niewiele ma to wspólnego z pracą rozumianą np. jako kategoria filozofii polityki, dużo więcej zaś - ostatecznie - właśnie z Heideggerowskim „odpuszczeniem” (Gelassenheit), opisanym tylko w nieco bardziej dynamicznej, teatralnej stylistyce. I znów wybór Hamleta na głównego protagonistę tekstu wydaje się bardzo zasadny - i on stale „wsłuchuje się” w głosy i chce być „gościnny wobec duchów” - ostatecznie nie doprowadza to jednak do niczego innego niż tragedii.

$\mathrm{Na}$ fakt, że koncepcja praktyki jest u Derridy niewystarczająca i zagrożona redukcją do żałobnych negocjacji, jakie podmiot prowadzi z samym soba, wskazuje także Antonio Negri w swym eseju Uśmiech Widma. Wcale nie chodzi przy tym o wyzywanie Derridy od skrajnie niepraktycznych „tekstualistów”, ale o coś bardziej zasadniczego:

Nie chcemy powiedzieć, że praktyczne zastosowanie dekonstrukcji okazuje się jedynie kompilacją dekryptaży i demistyfikacji lingwistycznego rozplenienia - z pewnością nie o to chodzi, a nawet jeśli by tak było, to same te operacje nieodłączne są od konotacji ontologicznych. Konotacja ta jednak jak może broni się przed tym, by okazać się konstytutywna. (...) Wiążąc się z nową społeczną siłą masow ej inteligencji, radykalna forma marksizmu jest w stanie konstruktyw nie odpowiedzieć na now e formy regulacji kapitału i wyzysku pracy niematerialnej. W sw ej przeciwnej skrajności jednak dekonstrukcja zakreśla jednoosobowy, transcendentalny horyzont, tracąc przy tym związek z praktyką i rejterując, gdy tylko zidentyfikowała czynnik możliwego określenia sprawiedliwości. Tym większa to szkoda, bo Widma Marksa stanowić mogłyby istotne w prowadzenie do nowej praktyki (Negri 2008, 15).

Jak stwierdza Negri, Derrida z niezwykła przenikliwością śledzi (albo wręcz przewiduje) transformacje, jakim podlega rzeczywistość społeczna w postprzemysłowej epoce kapitalizmu. Globalna spektralizacja rzeczywiście pochłania wszystko, począwszy od kapitału (którego władza im mniej przejrzysta, tym bardziej skuteczna; „,widmowość” jest więc w jego najlepszym interesie). Zapośredniczone przez Internet i sieci komunikacyjne procesy wytwarzania wartości okazuja się bazować na wcale nie mniejszym, choć lepiej ukrytym wyzysku, a bankowe spekulacje, operujące nieistniejącymi pieniędzmi zdolne są do wytwarzania jak najbardziej realnych katastrof. W tym kontekście „krytyka ekonomii politycznej” dokonana przez Derridę, jakkolwiek sformułowana bardzo ogólnie, celnie trafia w zasadnicze urządzenia gospodarki neoliberalnej, z którą - co należy przyznać - autor nie chce iść na żadne kompromisy (przykładem takiego dwuznacznie koncyliacyjnego podejścia, a jednocześnie obiektem zdecydowanej krytyki Derridy jest tu Francis Fukuyama). To jednak 
- jak wskazuje Negri - jedynie poziom opisu fenomenologicznego, w którym Derrida „nie chce zobaczyć ruchu ontologicznej konstytucji i/lub produkcji podmiotowości” (Negri 2008, 13). Dlaczego? Negri stwierdza, że w tym względzie „dekonstrukcja pozostaje zakładniczką nieefektywnej i wyczerpanej definicji ontologii” (Negri 2008, 12). Tak jak - co słusznie zauważa ABR - u wczesnego Derridy krytyka podmiotowych pretensji do pełni obecności bazowała na dawno przebrzmiałej, idealistycznej koncepcji podmiotu (Bielik-Robson 2008, 103); tragiczny pięknoduch Hamlet skądinąd znów dobrze obrazuje ten wątek. Głęboka transformacja zaobserwowana na poziomie fenomenologicznym wymaga przeformułowania na poziomie ontologii, na które autor nie jest się w stanie zdecydować. Dlatego widmontologia jest najwyżej hermeneutyką efektów tej zmiany, i choć świetnie nadaje się do opisu doświadczenia żyjącego w epoce spektralnej podmiotu (,prowadzącego z widmami estetyczną czy intelektualną grę, której pełno jest w popkulturze”), to jednak zatrzymuje się przed uznaniem ontologicznej, realnej, a nie widmowej faktyczności wyzysku i niepowstrzymanej niczym akumulacji wartości dodatkowej. $\mathrm{Na}$ gruncie widmontologii niezwykle trudno też formułować nie tylko rewolucyjne, ale w ogóle jakiekolwiek materialistyczne postulaty, skoro podważa ona kryteria rozróżniające realność i wagę poszczególnych głosów: trudno tu nawet odróżnić status halucynacji lub zjawy unoszącej się nad grobem od kamienia, z którego ten jest zrobiony. Ta niekonsekwentna, doprowadzona do połowy krytyka społecznej ontologii przekłada się wreszcie na całkowicie nieoperatywną (by nie powiedzieć - reakcyjna) teorię czasowości, której tylko apodyktyczna, totalna asynchronia pozwala połączyć sprzeczne perspektywy: żałobną, wsłuchaną w przeszłość retrospekcję i mesjańskie „otwarcie na przyszłość”. „Widma marksizmu” - konkluduje Negri - tak, zapewne, ale raczej nie komunizmu, a to o nie przede wszystkim chodziło Marksowi. Komunizm zakłada bowiem ontologiczną transformację, która kończy z rozpamiętywaniem przeszłych błędów:

Nowy eksperyment komunizmu przychodzi do życia wraz z zerwaniem z pamięcia. Zerwanie to różni się od wszelkiej melancholii i resentymentu. Jasne staje się więc, że w teraźniejszości, pod nieobecność duchów lub w ich tłumie, ujawnia się jedyna rzeczywista ciagłość: ciagłłość walki, ducha konstytuującego, ontologicznej przemocy transformacji. Wyczekiwane wydarzenie sprawia, że przeszłość eksploduje. (...) Widmo komunizmu nie jest tylko produktem krytyki; jest także, ponad wszystkim, namiętnościa, destrukcyjną dla świata, w którym rządzi kapitał i konstytutywną dla świata wolności, „rzeczywistym ruchem, który znosi stan obecny” (Negri 2008, 15). 
Nasza krytyka książki Derridy ma jeszcze jeden ważny wątek, być może najważniejszy, który w sposób niepozostawiający wattpliwości udowadnia, jak bardzo zawodna okazuje się reklamowana przezeń koncepcja sprawiedliwości. Zawodna i abstrakcyjna, także w sensie heglowskim - czyli niedająca się zapośredniczyć i tak naprawdę bezsilna. Jako taka nie dysponuje ona żadnym argumentem, który dawałby gwarancję, że zdolna jest wypełnić obietnice składane temu, co jednostkowe (dostarcza za to całego spektralnego arsenału „wymówek”). By przedstawić to na konkretnym przykładzie, użyjemy metody samego Derridy, wykazującej, że cenę za „spójność” teorii płaci zawsze to, co wyłączone, pozostające na jej marginesie. Albo poza nim, tak jak w tym przypadku. Myślimy tu o Ofelii. Jej imię nie pada w książce ani razu; wśród tylu deklaratywnych i podniosłych zdań na temat sprawiedliwości nie ma miejsca na choćby jedno zdanie o Ofelii. Tyle subtelnych roztrzasań o odpowiedzialności, długu, winie, nierozstrzygalności, o nawiedzających głowę duchach i ani wzmianki o Ofelii, jej nieszczęśliwej miłości, szaleństwie i śmierci. Czy jednak nie jest tak, że także dramatyczne życie Ofelii zawieszone jest - i to bez żadnych paranormalnych interwencji - między obecnością i nieobecnością? I że także ono, czy raczej właśnie ono jest pozycją, z której zasadnie kwestionować można by niesprawiedliwość? Zakładając, że czytelniczka zna treść dramatu Szekspira, nie będziemy jej przypominać; jeśli zaś idzie o złożoną wymowę, jaką niesie historia Ofelii, a także jej symbolikę i historię jej interpretacji - odsyłamy do inspirującego studium Katarzyny Czeczot pod tytułem Ofelizm. Romantyczne zawtaszczenia, feministyczne interwencje. Autorka tropi w nim istnienie pewnej - mówiąc bardzo ogólnie - ofelicznej tradycji i błyskotliwie interpretuje jej wizualne i tekstualne realizacje, które - choć zazwyczaj marginalne wobec przedstawień tragedii Hamleta - opowiadaja historię ciekawsza, o dużo bardziej subwersywnym potencjale. Jego wydobycie wymaga jednak rozerwania siatki sztywnych podziałów, na których rozpisana jest historia Ofelii i które sprawiaja, że bardzo trudno jest zrozumieć, co postać ta chce powiedzieć. Pisze Czeczot:

Obrazy Ofelii (...) oceniane w binarnej logice tradycyjnej filozofii - skupiaja w sobie szereg wyobrażeń fundujących wizję świata, w której uprzywilejowane miejsce przypada męskiemu, białemu, heteroseksualnemu podmiotowi mającemu wyłączność na dostęp do władzy/wiedzy, rozumianych jako ujarzmianie nie-ludzkiej, pasywnej natury. (...) Ofelizm jest językiem sentymentalnej rewolucji w uczuciach, która wywraca na nice dotychczasowe podziały płci. Jest on również konstelacją tropów kodująca społeczny przewrót (Czeczot 2016, 127).

Derrida, przenikliwy demaskator fallogocentryzmu, gdzie indziej tak czujny na kwestie podziałów i wykluczeń nadbudowanych na różnicy płci, w omawianej tu książce okazuje się zupełnie ich nie dostrzegać. Przeciwnie, za dobra monetę bierze rozwlekłe, neurotyczne monologi Hamleta, nie zauważając, że ich przegadanie maskuje w istocie także 
niesprawiedliwość, jaka spotyka jego porzuconą przyjaciółkę. Tymczasem tylko Ofelia nie wybucha tu chęcią zemsty i tak naprawdę tylko ona mogłaby mieć coś do powiedzenia w kwestii „ekonomii daru”. Wyraźnie uwiedziony hamletyczno-heideggerowskim niezdecydowaniem uogólnia Derrida tę postawę, odnajdując w niej rzekomą prawdę kondycji istot politycznych w ogóle. Zauważmy, że wynika stąd jeden jeszcze problem z Derridiańską koncepcja: $z$ jednej strony kontestuje ona model sprawiedliwości oparty na retrybucji i zemście, z drugiej jednak nie jest w stanie odżegnać się od fallogocentrycznego, patrymonialnego przekazu zza grobu, którego aporetyczny charakter wyznacza (i, naszym zdaniem, jednocześnie dość wąsko zamyka) horyzont owej mesjańskiej polityki. Niezauważona przechodzi dużo bardziej obiecująca możliwość innej sprawiedliwości - tej, którą wyrazić próbuje niesłuchana przez nikogo Ofelia, będąca skądinąd chyba jedyną mentalnie zdrową z ważnych postaci dramatu (przynajmniej dopóki nie wciąnnie jej szaleństwo owładniętych obsesją władzy, mściwych intrygantów, którzy nieustannie uciszaja dziewczynę i mówią jej, co ma robić). Ofelia jako jedyna odżegnuje się od przemocy i zemsty; jej dążenie do sprawiedliwości nie wyklucza realizacji zwyczajnej, „wyrosłej z natury” potrzeby szczęścia. Przeciwnie, udowadnia, jak ściśle te dwie potrzeby są ze sobą powiązane (to wątek, który powraca w refleksji Adorna; dlatego też dziwi nas, że jego wnikliwa czytelniczka, Agata Bielik-Robson, gdzie indziej tak wrażliwa na te kwestie, w swej interpretacji Widm Marksa nie zwraca uwagi na powyższe problemy). Ofelii także przysługuje jedynie połowiczna obecność, jednak nie z uwagi na żadna ponowoczesną spektralizację, ale jak najbardziej konkretne, materialne i dyskursywne, starsze niż sam Szekspir patriarchalne praktyki wykluczania. Derrida, skupiony na poszukiwaniu odpowiedniej miary dla zalecanej gościnności wobec widm, nie komentuje tragedii Ofelii ani słowem, nie widzi też, że to raczej ona mogłaby wprowadzić do tej historii potencjał jakkolwiek pokrewny z duchem marksizmu. Nieobecność Ofelii świadczy o jeszcze jednym przemilczeniu, naszym zdaniem zasadniczym. Derrida nie konstatuje bowiem, że sprawiedliwość wobec umarłych nie może zrealizować się nigdzie indziej niż w relacjach, jakie łączą nas z żywymi.

Mimo zgłaszanych tu problemów, które naszym zdaniem nie pozwalają czytać książki Derridy jako aktualnej propozycji politycznej, trudno odmówić trafności wielu jej rozpoznaniom z zakresu krytyki ponowoczesnej kultury. Nie brakuje jej również literackiego rozmachu czy wręcz geniuszu: performatywny, niezwykle błyskotliwy styl, pomysłowość i rozpiętość skojarzeń czynią jej lekturę ekscytująca. Liczba jej apologetycznych recenzji jest jednak tak duża, że zdecydowaliśmy nie powtarzać wygłaszanych w nich superlatywów, co wcale nie znaczy, że nie jesteśmy pod wrażeniem wielu genialnych spostrzeżeń autora. Czy jednak, choćby na gruncie samej krytyki owej spektralizującej, rozmywającej wszystko i nieustannie nawiedzanej przez nieuchwytne widma kultury, mówi Derrida coś, co może być dla nas, tu i teraz, jakkolwiek odkrywcze, informujące bądź pomocne? Wydaje się raczej, że 
rację mimo wszystko miał Marks, który egzorcyzm owych spektralnych sił uznawał za niezbędny warunek jakkolwiek odpowiedzialnej i niedającej się zbyt łatwo zwieść filozoficznej procedury. Nie chodzi zresztą o „egzorcyzm”, tak samo jak nie chodzi o żadną teologię. Chodzi właśnie o krytykę w jej mocnym, ale i ścisłym sensie, krytykę, która prześwietla i rozkłada swój przedmiot, po to jednak, by wyznaczyć mu właściwą miarę, formę, w której stanie się on wyraźniejszy i bardziej podobny do samego siebie. Duch dekonstrukcji tymczasem „lata tam gdzie chce” i raczej - jak sama spektralna epoka - anuluje i rozmywa granice, nie pozwalając dekonstruowanym pojęciom choćby na chwilę okrzepnąć w określonym kształcie. Dlatego dekonstrukcja rzeczywiście tylko w umownym znaczeniu nazwana być może „radykalizacja” marksowskiego gestu krytyki - bierze być może podobny zamach, ale sens i efekt tego ruchu okazuja się odmienne. Należy oczywiście docenić, że późny Derrida dostrzega wartość politycznych stawek, a nawet z mesjańskim (choć bez Mesjasza) zacięciem wieszczy potrzebę organizacji Nowej Międzynarodówki. Można się jednak obawiać, że bez jakiegokolwiek „warunkującego ją interesu: państwowego, etnicznego, klasowego, ekonomicznego a także gatunkowego" (Derrida 2016, 59) musiałaby to być Międzynarodówka Widm. 


\section{Wykaz literatury}

Bielik-Robson, Agata. 2008. „Na pustyni.” Kryptoteologie późnej nowoczesności. Kraków: Universitas.

Bielik-Robson, Agata. 2016. „Światełko na mokradłach.” Literatura na świecie $3 / 4$.

Czeczot, Katarzyna. 2016. Ofelizm. Romantyczne zawlasžczenia, feministyczne intervencje. Warszawa: IBL PAN.

Derrida, Jacques. 2016. Widma Marksa. Stan dtugu, praca żałoby i Nowa Międzynarodówka. Tłum. Tomasz Załuski. Warszawa: PWN.

Eagleton, Terry. 2008. „Marxism Without Marxism.” W Ghostly Demarcations. A Symposium on Jacques Derrida's „Specters of Marx”, red. Michael Sprinker. London-New York: Verso.

Marks, Karol. 1947. Krytyka programu gotajskiego. W Marks, Karol. Dizieła wybrane. T. 2.

Momro, Jakub. 2016. Widmowa teraźniejszość. http:/ /www.dwutygodnik.com/artykul/ 6411 widmowa-terazniejszosc.html.

Negri, Antonio. 2008. „Specters Smile.” W Ghostly demarcations. A Symposium on Jacques Derrida's ,Specters of Marx”. Red. Michael Sprinker. London-New York: Verso.

Sadzik, Piotr. 2016. „Bądźmy realistami, żądajmy dekonstrukcji.” www.praktykateoretyczna.pl/piotr-sadzik-badzmy-realistami-zadajmy-dekonstrukcji

Szekspir, William. 1958. Hamlet. Tłum. Józef Paszkowski. W Drieła dramatyczne. T. 6. Warszawa: PIW. 
Jędrzej K. Brzeziński - student w Instytucie Filozofii Uniwersytetu Warszawskiego, gdzie przygotowuje pracę magisterską poświęconą estetyce Jacques’a Ranciere’a. Tłumacz książki Gilles'a Deleuze’a Spinoza. Filozofia praktyczna.

\section{DANE ADRESOWE:}

Instytut Filozofii Uniwersytetu Warszawskiego

Krakowskie Przedmieście 3

00-097 Warszawa

EMAIL: jedrzejbrzezinski@gmail.com

CYTOWANIE: Brzeziński, Jędrzej. 2016. Widmowa aktualizacja marksizmu czy spektralna bujda. Praketyka Teoretyczna 1(19): 290-302.

DOI: $10.14746 /$ prt.2016.1.14

AUTHOR: Jędrzej Brzeziński

TITLE: Spectral Actualization of Marxism or Spectral Humbug

ABSTRACT: The article is a critical reading of Jacques Derrida's Spectres of Marx. Apart from presenting the Eagleton's and Negri's critical interpretations and philosophical unproductiveness of Derrida's proposals, I also try to show their inability to fulfill the ethical and political promises, which they makes.

KEYWORDS: Derrida, marxism, hauntology, ophelism, deconstruction 